\title{
A rare cause of superior vena cava syndrome
}

\author{
Aram Barbaryan, Alaa M Ali, Nasir Hussain, Aibek E Mirrakhimov
}

Department of Internal Medicine, Saint Joseph Hospital, Chicago, Illinois, USA

\section{Correspondence to}

Dr Aibek E Mirrakhimov, amirrakhimov1@gmail.com

\begin{tabular}{|l|}
\hline To cite: Barbaryan A, \\
Ali AM, Hussain N, et al. \\
BMJ Case Rep Published \\
online: [please include Day \\
Month Year] doi:10.1136/ \\
bcr-2013-008904 \\
\hline
\end{tabular}

\section{DESCRIPTION}

A 67-year-old African-American woman presented to the hospital with a several months' history of bilateral breast swelling, shortness of breath, voice hoarseness, head fullness and facial swelling. On physical examination, the patient was found to have engorged chest wall veins, bilateral arm and breast oedema and fullness of supraclavicular areas. Vital signs were normal and initial blood tests including complete blood account, complete metabolic profile did not reveal any abnormality. Her medical history was significant for hepatitis $\mathrm{C}$ virus infection, stroke and hypertension.

Chest x-ray was normal and CT of the chest with contrast showed chronic superior vena cava (SVC) obstruction with multiple chest wall lateral vessels consistent with chronic thrombus/fibrosis (figures 1 and 2 , respectively). There were no lymphadenopathy and lung was free of infiltrate and consolidation.

Upon further questioning, it was found that 15 years ago the patient had an acute pancreatitis for which she had a right subclavian-implanted port placed for almost 5 years. Subsequent hypercoagulable work up was negative and CT of the abdomen and pelvis was unrevealing. Patient was taken for venography with potential percutaneous

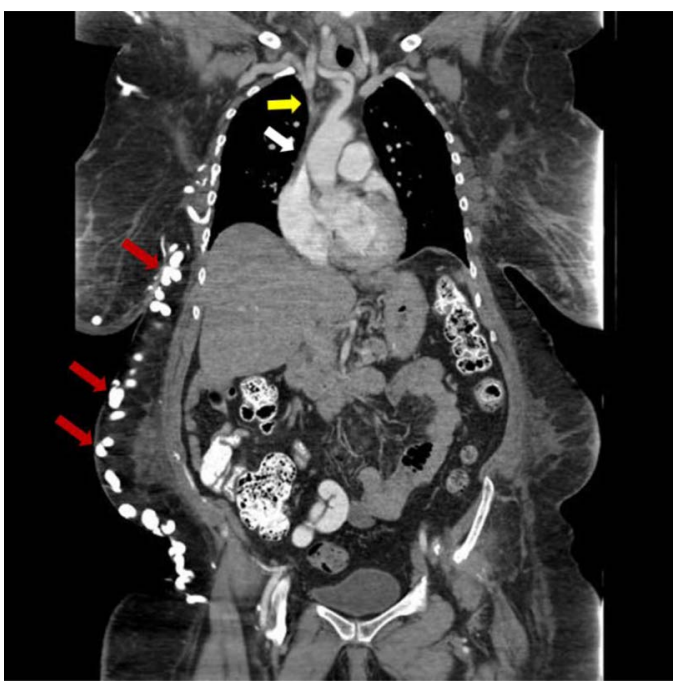

Figure 1 CT of the chest, abdomen and pelvis following enteric and intravenous contrast administration, coronal view. Chronic complete obstruction of left brachiocephalic vein (yellow arrow) and superior vena cava (white arrow). There are extensive collateral vessels along the chest walls more pronounced on the right side (red arrows) extending to the level of the inguinal regions. There are multiple prominent enhancing right intercostal collateral vessels also. There are no enlarged mediastinal or hilar lymph nodes as well as no soft tissue densities were identified in the lungs. The liver is unremarkable. The spleen and pancreas are unremarkable as are the kidneys and adrenal glands. There is no evidence of ascites or enlarged pelvic lymph nodes.

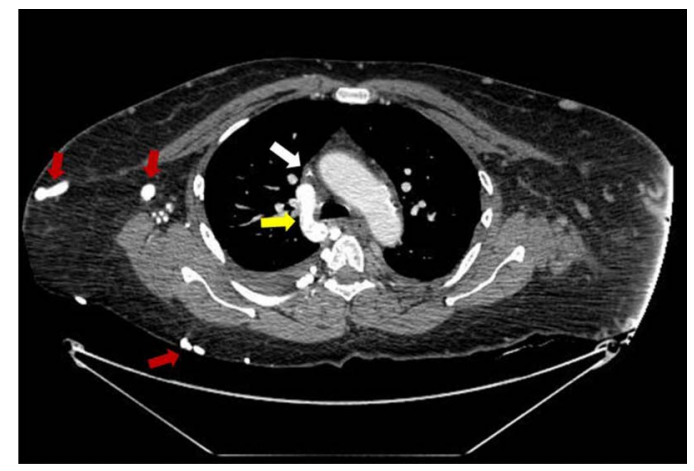

Figure 2 CT of the chest with intravenous contrast material-axial images of the chest were obtained following the intravenous administration of $100 \mathrm{ml}$ of Optiray 320 and reconstructed in coronal and sagittal planes. Dilated azygos vein (yellow arrow) draining into the nearly completely obstructed superior vena cava (white arrow). The superior vena cava is very small in calibre and minimal if any intravenous contrast is identified in it (white arrow) and this is likely related to chronic thrombus/fibrosis. There are collateral vessels along the chest walls more pronounced on the right side (red arrows). There are no enlarged mediastinal or hilar lymph nodes as well as no soft tissue densities were identified in the lungs.

intervention. Venography confirmed chest CT findings showing complete occlusion of the SVC with extensive collateralisation (figure 3). Unfortunately,

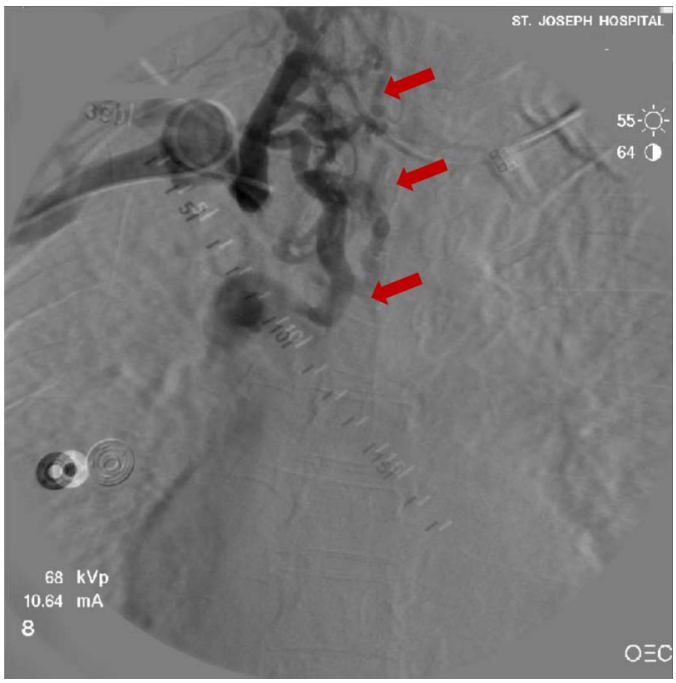

Figure 3 Selective catheterisation of the right subclavian vein. Contrast venography revealed a complete occlusion of the superior vena cava. The right internal jugular vein filled the azygos venous system by way of large venous collaterals (red arrows). The patient did have extensive collateralisation, suggesting chronicity to the occlusion. There was no backfilling of the left brachiocephalic vein seen on delayed contrast imaging. 
we could not cross occlusion with multiple guidewire and catheter combinations. Given fairly well-developed collateral vessels and non-debilitating nature of her symptoms, the decision was made to manage her conservatively with diuretics and compression garment to upper extremities.

Malignancy is considered the most common cause of SVC syndrome accounting for $60-90 \%$ of the cases. Increasing use of intravascular access devices like pacemakers, indwelling venous catheters made the benign aetiology as an emerging cause of SVC syndrome. Symptoms typically develop over a few weeks and then improve due to development of collateral vessels. Percutaneous stenting is the mainstay of treatment of nonmalignant SVC syndrome. ${ }^{1-3}$
Contributors All authors contributed equally to the composition of this manuscript.

Competing interests None.

Patient consent Obtained.

Provenance and peer review Not commissioned; externally peer reviewed.

\section{REFERENCES}

1 Rice TW, Rodriguez RM, Light RW. The superior vena cava syndrome: clinical characteristics and evolving etiology. Medicine (Baltimore) 2006;85:37-42.

2 Yellin $A$, Rosen $A$, Reichert $N$, et al. Superior vena cava syndrome. The myth -the facts. Am Rev Respir Dis 1990;141:1114-48.

3 Smayra T, Otal P, Chabbert V, et al. Long-term results of endovascular stent placement in the superior caval venous system. Cardiovasc Intervent Radiol 2001;24:388-94.

\section{Learning points}

- Widespread use of indwelling vascular devices has led to increasing incidence of superior vena cava (SVC) syndrome not caused by malignancy.

- Patient might develop symptoms of SVC syndrome several years after removal of intravascular access device.

Copyright 2013 BMJ Publishing Group. All rights reserved. For permission to reuse any of this content visit http://group.bmj.com/group/rights-licensing/permissions.

BMJ Case Report Fellows may re-use this article for personal use and teaching without any further permission.

Become a Fellow of BMJ Case Reports today and you can:

- Submit as many cases as you like

- Enjoy fast sympathetic peer review and rapid publication of accepted articles

- Access all the published articles

- Re-use any of the published material for personal use and teaching without further permission

For information on Institutional Fellowships contact consortiasales@bmjgroup.com

Visit casereports.bmj.com for more articles like this and to become a Fellow 